\title{
Distance Learning of Indonesian Early Childhood Education (PAUD) during the Covid-19 Pandemic
}

\author{
Heny Solekhah \\ Research Synergy Foundation
}

\begin{abstract}
The outbreaks of Covid-19 influence Indonesian education nationally, including early childhood education (PAUD). Since the school closures in March, the teachers have attempted to implement distance learning. This study is conducted in a school in Kendal. The teacher shared her experiences in conducting the learning based on the emergency curriculum. It is found that the government has given support by publishing the twelve books for the learning at home policy and providing the internet data. Most of the books are about playing with children and positive communication. Parents' roles in distance learning have a greater proportion than the teachers. Parents in this situation have the duties to supervise the learning, to conduct the learning, and to assist teachers in the assessment. The teachers construct the weekly lesson plan, communicate the steps of the learning process, and evaluate the students' progress. However, both teachers and parents experience barriers due to the lack of skills in using technology and the inability to provide learning materials to support six aspects of child development..
\end{abstract}

Keywords: Early Childhood Education, PAUD Teachers, Distance Learning, Belajar dari Rumah, Covid-19 Pandemic

This is an open access article under the CC-BY-NC-SA license.

\section{INTRODUCTION}

Covid-19 is declared as a pandemic by the World Health Organization in March 2020 (Millard, 2020). This new disease has changed the countries in the world in many aspects of humans' life, such as economic, social, and education. The obligation to apply health protocol such as wearing a mask, washing hands, avoiding the crowd, and being physically distanced with other people has greatly influenced how the people around the world communicate and fulfill their basic necessities.

Responding to the Pandemic, the Indonesian government announced Surat Edaran Kemendikbud (an announcement letter from the Ministry of Education) stating that the students in each level must learn from home (Kementerian Pendidikan dan Kebudayaan, 2020). The reaction from the schools was dramatic. The face-to-face activities at school that involves the students were prohibited while the teachers took a turn in working in the office. This condition had continued until the end of academic study in June 2011, leaving all schools, especially early childhood education in uncertainty.

The minister of national development planning, Suharso Monoarfa, states that the number of unemployed Indonesian people increases by 3,7 million people during the Covid-19 (Fauzia, 2020). In other words, the parents who used to work in the office are now more likely to spend their time because of working at home, or unemployment, or layoff due to the impact of the Pandemic. In Kendal Regency, the location where the study was conducted, there had been 1,377 people who experience layoffs since the beginning of the outbreaks (ayosemarang.com, 2020). As a consequence, parents would have more tend not to send their children because they think that it is not necessary. The ministry of education and culture also states that the number of enrolled 
students in early childhood education during the outbreaks reduces greatly (Makdori, 2020). The early childhood education that has put enormous energy to be established and developed due to the limitation of funding and social support (Solekhah, 2019) is facing a giant challenge to overcome.

The government also attempts to provide distance-learning material through Televisi Republik Indonesian (Indonesian Television Broadcasting), and other online applications such as Rumah Belajar, PAUD Pedia, Anggun Paud, and others. Besides, the emergency curriculum is implemented as a response to the school closures in Indonesia in which the national curriculum content is reduced based on the level or grade (Dikdas, 2020). However, during distance learning, the parents whose young learners' study at home have difficulty in teaching their children (Rama, 2020). Therefore, it is important to understand the expectation of the government during learning at home and the implementation of the urgent curriculum in the real situation based on the context of the school and the family condition.

\section{THEORETICAL PERSPECTIVE}

Family is the most influential factor in child development. The level of education and financial stability of the parents, for example, could be the influential factors in how to treat the children, not only in making sure that their children consume healthy food but also in providing proper education and a safe environment. In developed counties, for instance, in order to develop math and language skills, experiences at home, including the caregiver, should be part of early learning strategy (Maloney, Converse, Gibbs, Levine, \& Beilock, 2015). It means that if the parents could be good educators, there is a likelihood that their children would develop excellently. On the contrary, Low Socio-Economic Status is a predictor of multi-dimensional aspects of children's development, such as psychosocial and physical stressors and educational outcomes (apa.org, n.d).

Many countries are focusing on early childhood education because it has important roles in developing six literacy skills in the 21st century, such as reading, numeracy, science, digital literacy, financial literacy, and cultural literacy (Eko BH, 2020). It is expected that the young generation would be able to develop critical thinking, to study independently, and to be future leaders. In order to develop cognitive, affective, and psychomotor, games are the main activities for the children.

Playing games is the world of very young children (Kementerian Pendidikan dan Kebudayaan, 2020i). Children will always try to find opportunities to play and use any tools as toys. Playing could develop the cognitive aspects of the children because of creativity, problem-solving, and the ability to understand new concepts. Besides, through playing, motoric ability and concentration would be developed. The children would do physical activities to exercise arms and fingers as well as increase their communication skills.

Playing math for children could be done by matching objects with the same color, classifying objects based on the special patterns, comparing the similarities and differences of objects, and introducing basic geometry (Kementerian Pendidikan dan Kebudayaan, 2020b). Counting numbers, comparing which number is larger than another number, sorting numbers, and measuring with rulers could increase the numeracy skills of the children. Explorations and songs are joyful activities that could be done both inside or outside the house.

Playing science is also a fun learning activity that involves an inquiry process for children. The experiments by using ice block, for example, could be a game that teachers the change of solid substances to be liquid. Having physical interaction with a pet also gives the opportunity to learn about animals. In playing science, parents could ask some questions to the children and encourage them to use the five senses to observe and recognize certain objects. Interesting picture books and 
experiments are more interesting to the children (Kementerian Pendidikan dan Kebudayaan, 2020d).

Some examples of playing activities are usually done at schools with the students and their peers. However, the covid-19 has overtaken the interaction of the students from normal life to a new normal. Their school activities could not be done as usual, but it has transformed into the online mode. Online learning has advantages and drawbacks. By learning online, both the learners and teachers should not be in the same place. However, everyone may have limitations on distance learning, such as the ability to operate the devices, the necessity of adults' supervision and involvement, and the limited social interaction (J. Kim, 2020). It is hard to implement non-face-toface learning for very young learners. Not only due to internet access, but also the device and the parents' ability in delivering the learning activities (Al Ansori, 2020). Therefore, it is important to know how distance learning in early childhood education is implemented.

\section{RESEARCH QUESTIONS}

1. How does the Indonesian government support distance learning in early childhood education?

2. What are the roles of parents and teachers in distance learning?

3. What are the barriers to implement the urgent curriculum?

\section{METHODOLOGY}

The research is a descriptive study taken in an early childhood school in Kendal, Indonesia. The data collected was the lesson plan, the portfolios of the students, and the interview. Due to the covid-19, communication via WhatsApp was done. The teacher sent the copy of the documents of the lesson plan, the samples of students' portfolios, the sample of the screenshots of her class activity on WhatsApp group, and the copy of electronic books published by the government. She also explains how the new academic year has started since July 2020. The finding is then compared to the news and the literature.

\section{FINDING AND DISCUSSION}

The current situation of early childhood education is challenging. The schools and the teachers should deal with the decrease in the enrollment of the students while the parents have different abilities to conduct learning from home policy. The government has done some intervention in order to make the implementation better; however, the socialization is not reaching all schools and parents.

\section{Indonesian Government's Support for Early Childhood Education}

The minister of education and culture has responded quickly in order to prevent the spread of coronavirus disease towards the teachers and very young children. Health protocol is the priority to protect the people. Therefore, the implementation of Biaya Operasional and Biaya Operasional Sekolah (Government's educational funding) become more flexible to be allocated for health apparatus, such as masks, face shields, soap, and other spendings (Saputri, 2020). In addition, this funding could also be spent to increase the teachers' salaries and transportation costs.

Kendal, the location of the study, is classified as a red zone due to the increase of the Covid19 patients. The health protocol is the obligation of every educational institution. In the school where this study was conducted, the teachers wear masks and face shields when they worked at school. During the admission process, the parents and children who were willing to enroll in the school must wear masks and wash their hands, and did physical distancing. The thermo-gun was also used to check their temperatures. The equipment of health protocol helped both parents and teachers in doing the activities. 
The second support given by the government was the internet data. The government provides the students with 20 Gigabytes per month for four months. The subsidy included 5 Gigabytes for accessing all websites and mobile applications, while the majority of it was for learning purposes, such as video conference via Zoom or other video calls. It was also suggested that the data is used wisely for learning, and the students must not rely on the gadget (Trimuliana, 2020). In September, 946 thousand mobile numbers consisting of PAUD teachers and parents received the internet subsidy, and around 7,2 million additional internet vouchers were distributed in October 2020 (Eko BH, 2020a). By protecting income and health, the economic recovery will reduce the impact of lack of social cohesion (Razavi, Behrendt, Bierbaum, Orton, \& Tessier, 2020).

In this school, however, not all the teachers and students receive internet subsidy. Only 20 students and three teachers could obtain this aid. It was unclear why the rest of them, one teacher and five students, were not helped. All of the data had been submitted to the system, but this problem remained unchanged. Therefore, there should be further followed by the school administrators to proceed and solve the problem.

The students in early childhood education and elementary schools experience the greatest negative impact of distance learning. Therefore, the government published 12 guidance books to help both parents and teachers in conducting learning from home policy (Indriani, 2020). The books are free to access on the website of the Indonesian ministry of education. The teacher in this study explained that she received only four books from a teacher in a different school who finished a workshop of Belajar dari Rumah (learning at home). Unfortunately, the participants of the workshop were limited, and she could not attend the session. These books were printed and still need to be read carefully before they were applied in her school.

The directorate of PAUD is also preparing four workbooks of national early childhood education. The books would be standardized based on the minimum standard of education. The books include the guidance of developing PAUD books, guidance for parents and teachers to be authors of PAUD books, room managements for PAUD, and the standard of child-friendly school (Eko BH, 2020b).

\section{Teachers' Roles during the Pandemic}

To build positive communication between the parents and early childhood teachers during distance learning, the Indonesian government provides the guidebook. The teachers are encouraged to be able to observe the students during the learning, to convey the messages effectively, to listen carefully, to respect others, to be confident, and to understand other people's emotion(Kementerian Pendidikan dan Kebudayaan, 2020g). By having positive communication, the parents and the teachers would have the same understanding, to build joy, to have a positive influence, to have better social relationships and action.

Before implementing learning at home, the teachers in early childhood education are obliged to assess the cognitive aspects and the non-cognitive aspects of the students. The cognitive includes the ability of the learners to do the activities without the teachers' supervision. The noncognitive includes the financial ability of the family and the mental health of the students (Putsanra, 2020). The former minister of Education, Anies Baswedan, states that the teachers in early childhood education could strengthen their positions and roles as the agent of parenting education during the Pandemic because they have opportunities to encourage parents' awareness of character education (Jatnika, 2020).

During the Pandemic, the teachers are assigned to develop Rencana Pelaksanaan Pembelajaran Mingguan (RPPM) or weekly lesson plans based on the learning aims and the context of students. The lesson should address the cultural and social conditions of the students' family and the available resources at home (Kementerian Pendidikan dan Kebudayaan, 2020j). The instruments would be beneficial to help the children do experiment, exploration and investigation 
of their surroundings (Kementerian Pendidikan dan Kebudayaan, 2020i). A lesson plan should contain the steps of learning focusing the students' characteristics such as age, ability, and need. Teachers then could communicate with the teacher assistant via a short message service or WhatsApp to discuss the lesson plan. Otherwise, the teachers develop the lesson plan by themselves. The lesson plan is not only useful for the development of six aspects of children, but also for guiding the parents in preparing the learning materials.

The teacher should use the guideline from Permendikbud number 137 in 2014 on the national standard of early childhood education in order to understand the standard of students' developmental achievement; the core competence and the basic competence based on Permendikbud number 146 in 2014 on the 2013 curriculum; and the school unit curriculum. The learning should be fun for the students and parents, and they have the options to choose the activities and learning materials within a week. The teachers communicate the activities only without explain the detail of the lesson plan.

It is expected that everyone could maximize their smartphone for learning purposes, such as video conference, virtual class, and cloud storage. Hence, the Directorate of PAUD in Indonesia launches tutorials for online media, a pocketbook of playing music and movement, a pocket of crafting book, and the children's assessment guidance in distance learning (Kementerian Pendidikan dan Kebudayaan, 2020c, 2020e; Kementerian Pendidikan dan Kebudayaan, 2020; Kementerian Pendidikan dan Kebudayaan, 2020h).

The children could play at home with their parents, and the task of the teachers is to make sure that the parents and children could play by using the available equipment in their houses. Therefore, lesson planning is important (Kementerian Pendidikan dan Kebudayaan, 2020j).

In this study, the teacher created a weekly lesson plan to be implemented. Then, she sent the motivational messages via WhatsApp about the weekly activities to be done. She motivated the parents to be active in using the smartphone to access the learning materials provided, such as songs on YouTube, and other pictures. Every two days, she received photos or videos of the students doing the activities. In conclusion, teachers' roles were reduced significantly. They worked more as the investigator to assess the ability of the parents and students to do learning at home. They also became the learning planners and communicators to make sure that the learning process runs smoothly.

\section{Parents' Roles during the Pandemic}

Parents have larger roles in early childhood education. They were encouraged to spend more time with children to play together, appreciate the children, introduce health protocol, create consistent and flexible routine activities, to be assertive, manage stress, being opened, use online media carefully, budget the cost wisely (unicef.org, 2020).

Crafting is an activity to produce art by using different media in order to identify, develop, and connect the knowledge, talent, and experience to be a product (Kementerian Pendidikan dan Kebudayaan, 2020e). To play crafting at home, the parents are expected to create a stimulating environment at home by providing varied tools and ingredients; to give the children freedom to express themselves; and to make sure that their children feel comfortable and relaxed during the play (Kementerian Pendidikan dan Kebudayaan, 2020e). At home, the parents could provide stones, tissues, cardboard, twig, plastic, sponge, Lego blocks, and others (Kementerian Pendidikan dan Kebudayaan, 2020e).

In playing music and movement at home during the Pandemic, the parents are suggested to provide any safe tool that can produce sounds such as musical instruments, utensils, cd players, and others; to give the children's freedom to make any movement; and to make sure that their children feel safe, relaxed, and comfortable in playing (Kementerian Pendidikan dan Kebudayaan, 2020c). During the playing, the parents are also encouraged to respond positively to their children's 
progress by following their children's movement, obeying the rule of play, communicating effectively and positively, giving a compliment, introducing various songs, and avoiding criticizing their children (Kementerian Pendidikan dan Kebudayaan, 2020c). The responses were important because the appreciation would be an encouragement for the children to be more confident while the negative comments would decrease the children's self-esteem.

Literacy skills could be developed by playing with children's books, pictures, crayon, and other stationaries in order that the children get accustomed to the habit of reading and writing, although it does not mean that they must be able to read the words (Kementerian Pendidikan dan Kebudayaan, 2020a). They could tell the story based on what they see as a part of the 'reading' activity. The parents could read loudly so the children could listen to the words and increase their vocabulary. Reading with proper intonation would also develop the children's imagination. The parents could also ask their children to take part in creating the story by using dolls.

At the end of each activity, the parents would assist the teachers in observing and assessing their children during distance learning (Adit, 2020; Kementerian Pendidikan dan Kebudayaan, 2020h). The aspects of children's development are religious and moral values, motoric-physical growth, cognitive growth, language, social-emotional aspect, and art. In other words, the assessment includes the children's activities, communication ability, and expression by sending messages, photos, and videos to online media such as WhatsApp and email (Kementerian Pendidikan dan Kebudayaan, 2020h). Not only that, the children's growth, such as their weight and height, would also be reported. All the data are then transferred to be portfolios based on the dates and the identities. Then, the teachers would assess with four scales of development: "not developing", "start developing", "developing as expected", "developing very well" based on the weekly and monthly report. The report is then delivered to the parents in PDF form via email or WhatsApp.

In this study, the teacher explained that the video conference application, such as Zoom was not common for the parents. WhatsApp was considered a more friendly use. The learning process depended on the participation of the parents. Those who were active would send the progress more quickly and respond to the teachers' messages more attentively. On another hand, one parent did not give the sufficient response due since July and it took more effort in giving a reminder. However, the teacher could not force the parents if they were unable to do what was expected by the governments' policy.

\section{The Barriers to Implement of Urgent Curriculum}

The disruption of multifaceted aspects of life due to coronavirus would be a disaster not only for the economy but also for the health and development of the children (Benner \& Mistry, 2020). Covid-19 causes multisystemic impacts on the family due to the adaptation of uncertainty, the risk of adaptation, the risk of the corona diseases in an individual, family, and society (Rolland, 2020). Health concerns and financial difficulties hinder the parents' intention to send their children to kindergarten. While the parents should do home-schooling, the schools are struggling to survive, and the teachers might lose their jobs (Yuliana, 2020). The number of students enrolled in early childhood educational institutions decreases significantly, making some schools 'regrouped' or working together as a group cohort (Husna, 2020).

The schooling during the Covid-19 period makes the teachers worried about both personally and professionally as teachers, although they are making a successful effort in teaching remotely (Dayal \& Tiko, 2020). For caregivers, stress, and pain increase during the Pandemic (Sheth, Lorig, Stewart, Parodi, \& Ritter, 2020). Reopening the caregiver is also scary for both parents and teachers (Jeffs, Lucas, \& Walls, 2020). The lockdown, especially in poor countries, increases unemployment, poverty, and mental health problem (Pillay \& Barnes, 2020). 
Teaching early childhood education or Pendidikan Anak Usia Dini (PAUD) by using the distance-learning method is uneasy. Many teachers have difficulties in operating computers, in accessing stable internet, in communicating the messages to the parents, to plan a simpler lesson to be implemented by parents at home, and to assess the students' progress (Adit, 2020). Parents also experience the difficulties in supervising their children, using digital technology in early childhood learning, and in understanding the teachers' instructor (Kementerian Pendidikan dan Kebudayaan, 2020).

Learning in special condition has some principles that should be met. The learning process should encourage the learners to be active, optimistic, inclusive, adaptable, and respecting diversity (Kementerian Pendidikan dan Kebudayaan, 2020f). In order to be an early childhood education with high quality, each school should have the element of synergy, leadership, active children, and love (Fenech, Harrison, Press, \& Sumsion, 2020). Government plays an important role in mitigating long-term impacts of the Pandemic. It is suggested that the government should provide a family support package in order to fulfill the balanced nutrition for the family, screening for mental health status, support workers and professional community health, and the awareness of parenting support during the new normal (Yoshikawa et al., 2020).

The Pandemic would have a great impact on many sectors. It is important to prepare the learning post-pandemic, including providing a high subsidy for early childhood institutions in Indonesia. Australia itself provides a $100 \%$ subsidy for low-income families to pay the daycare services (Yuliana, 2020). In other words, since April, childcare in Australia is free (Yelland, 2020). After a new normal, it is necessary to implement innovation in early childhood education, such as the ratio between the teacher and the students to optimize the online interaction, understand the students' characteristics, and build a comfortable environment (D. D. Kim \& Neumann, 2020).

\section{CONCLUSION}

Distance learning burdens both the parents and the teachers. The parents' roles were complex not only as of the 'teacher assistant' but also as the assessor, while the teacher had to deal with the limited access to see the children directly and highly rely on the smartphone. These interactions were not optimum in order to increase the children's development. The government's assistance needs to be more holistic so that the parents could have more time and energy to do their roles better.

\section{DELIMITATION AND SUGGESTION FOR FURTHER RESEARCH}

This study was conducted in one school only due to the limited access to other schools, especially in maintaining intense communication. The researcher admits that different results might be different in other areas. Therefore, the finding of this study could not be generalized to other school conditions, especially because the various aspects might apply to other sites.

The Pandemic has influenced widely all over the world, and it is interesting to investigate not only from the point of view of teachers but also from the parents and the policymakers. It is suggested that further research would address the impacts of distance learning on parents' ability as the main facilitator, their rapports with the children, and the ability of policy makers to ensure the quality of early childhood education..

\section{REFERENCES}

Adit, A. (2020, 26 June 2020). Begini Cara Melakukan Penilaian Perkembangan Anak PAUD Selama Pandemi [These are the Ways to Assess the Children's Development during the Pandemic]. kompas.com. Retrieved from https://edukasi.kompas.com/read/2020/06/26/083044471/begini-cara-melakukanpenilaian-perkembangan-anak-paud-selama-pandemi

Al Ansori, A. N. (2020, 15 June 2020). Laksanakan PAUD From Home, Ini Beberapa Kendala yang Dialami Guru [Doing Early Childhood Education at Home, these are the Obstacles 
Experienced by Teachers]. liputan6.com. Retrieved from https://www.liputan6.com/disabilitas/read/4279245/laksanakan-paud-from-home-inibeberapa-kendala-yang-dialami-guru

apa.org. (n.d). Children, Youth, Families and Socioeconomic Status. Retrieved from https://www.apa.org/pi/ses/resources/publications/children-families

ayosemarang.com. (2020). Disnaker Kendal Catat 10 Perusahaan Masih Rumahkan Karyawan [The Department of Labor Force in Kendal Notes that 10 Companies Still Do Layoffs to the Employees]. ayosemarang.com. Retrieved from https://www.ayosemarang.com/read/2020/09/07/63275/disnaker-kendal-catat-10perusahaan-masih-rumahkan-karyawan

Benner, A. D., \& Mistry, R. S. (2020). Child Development During the COVID-19 Pandemic Through a Life Course Theory Lens. Child Development Perspectives, 14(4), 236-243. Retrieved from https://srcd.onlinelibrary.wiley.com/doi/abs/10.1111/cdep.12387. doi:https://doi.org/10.1111/cdep.12387

BH, E. (2020a, 23 October 2020). Bantuan Kuota BDR Telah Disalurkan Pada 35,5 juta Nomor Telepon [The Internet Subsidy was Delivered to 35,5 Million Mobile Phone Numbers]. Retrieved from https://anggunpaud.kemdikbud.go.id/index.php/berita/index/20201023214307/Bantuan -Kuota-BDR-Telah-Disalurkan-Pada-355-juta-Nomor-Telepon

BH, E. (2020, 27 October 2020). Investasi Pendidikan Dijenjang PAUD Menjadi Fokus Perhatian Banyak Negara di Abad 21 [Investment of Early Childhood Education Becomes the Focus of Many Countries in the Twenty First Century]. Retrieved from https://anggunpaud.kemdikbud.go.id/index.php/berita/index/20201027003238/Investas i-Pendidikan-Dijenjang-PAUD-Menjadi-Fokus-Perhatian-Banyak-Negara-di-Abad-21

BH, E. (2020b, 17 October 2020). Segera Terbit, Buku Panduan Menuju PAUD Berkualitas [Coming Soon, Guide Book for High Quality Early Childhood Education]. Retrieved from https://anggunpaud.kemdikbud.go.id/index.php/berita/index/20201017210917/SegeraTerbit-Buku-Panduan-Menuju-PAUD-Berkualitas

Dayal, H. C., \& Tiko, L. (2020). When are we going to have the real school? A case study of early childhood education and care teachers' experiences surrounding education during the COVID-19 pandemic. Australasian Journal of Early Childhood, o(0), 1836939120966085. Retrieved from https://journals.sagepub.com/doi/abs/10.1177/1836939120966085. doi:10.1177/1836939120966085

Dikdas, G. (2020, 7 August 2020). Kemendikbud Sederhanakan Kurikulum Pada Satuan Pendidikan Selama Masa Pandemi [The Ministry of Education and Culture Simplifies the Curriculum of School Unit during the Pandemic]. Retrieved from http://pgdikdas.kemdikbud.go.id/readnews/kemendikbud-sederhanakan-kurikulum-pada-satuan-pendidikan-selama-masapandemi

Fauzia, M. (2020, 28 July 2020). Akibat Covid-19, Jumlah Pengangguran RI Bertambah 3,7 Juta [Due to Covid-19, the Number of Jobless People Increases 3,7 million]. kompas.com. Retrieved from https://money.kompas.com/read/2020/07/28/144900726/akibat-covid-19-jumlahpengangguran-ri-bertambah-3-7-juta

Fenech, M., Harrison, L. J., Press, F., \& Sumsion, J. (2020). Using metaphor to illuminate quality in early childhood education. Australasian Journal of Early Childhood, 45(2), 197-210. Retrieved from https://journals.sagepub.com/doi/abs/10.1177/1836939120918482. doi:10.1177/1836939120918482

Husna, M. A. (2020, 14 October 2020). HIMPAUDI DIY Dukung PAUD yang Memilih Regrouping di Masa Pandemi Covid-19 [HIMPAUDI in Yogyakarta Supports Early Childhood Educational Institutions to be Regrouped during the Pandemic of Covid-19]. Tribunjogja.com. Retrieved from https://jogja.tribunnews.com/2020/10/14/himpaudi-diy-dukung-paud-yangmemilih-regrouping-di-masa-pandemi-covid-19 
Indriani. (2020, 28 August 2020). Dirjen : Murid PAUD dan SD paling terdampak belajar dari rumah. antaranews. Retrieved from https://www.antaranews.com/berita/1694470/dirjen-muridpaud-dan-sd-paling-terdampak-belajar-dari-rumah

Jatnika, Y. (2020, 9 August 2020). Pandemi Covid-19, Momentum Guru PAUD Jadi Agen Penggerak Pendidikan Keluarga [Covid-19 Pandemic is a Momentum for Early Childhood Education Teacers to be Agents of Parenting Education]. Retrieved from https://sahabatkeluarga.kemdikbud.go.id/laman/?r=tpost/xview\&id=249900874

Jeffs, E., Lucas, N., \& Walls, T. (2020). CoVID-19: Parent and caregiver concerns about reopening New Zealand schools. Journal of Paediatrics and Child Health, $n / a(n / a)$. Retrieved from https://onlinelibrary.wiley.com/doi/abs/10.1111/jpc.15234.

doi:https://doi.org/10.1111/jpc.15234

Kebudayaan, K. P. d. (2020a). Bermain Bahasa di Rumah dalam Melaksanakan Belajar dari Rumah. Jakarta: Kementerian Pendidikan dan Kebudayaan.

Kebudayaan, K. P. d. (2020b). Bermain Matematika yang Menyenangkan dengan Anak di Rumah [Playing Math Excitingly with Children at Home]. Jakarta: Kementerian Pendidikan dan Kebudayaan.

Kebudayaan, K. P. d. (2020c). Bermain Musik dan Gerak [Playing Music and Movement]. Jakarta: Direktorat Paud Kemdikbud 2020.

Kebudayaan, K. P. d. (2020d). Bermain Sains [Playing Science]. Jakarta: Kementerian Pendidikan dan Kebudayaan.

Kebudayaan, K. P. d. (2020e). Bermain Seni Kriya [Playing Crafts]. Jakarta: Direktorat Paud Kemdikbud 2020.

Kebudayaan, K. P. d. (2020f). Keputusan Menteri Pendidikan Republik Indonesia Nomor 719/P/2020 tentang Pedoman Pelaksanaan Kurikulum pada Satuan Pendidikan dalam Kondisi Khusus [The Practical Guidance of School Curriculum in Special Condition]. Jakarta: Kementerian Pendidikan dan Kebudayaan

Kebudayaan, K. P. d. (2020). Media Daring (Tutorial Webex, Zoom, dan Google Drive) [Online Media (The Tutorials of Webex, Zoom, and Google Drive)]. Jakarta: Direktorat PAUD Kemdikbud 2020.

Kebudayaan, K. P. d. (2020g). Membangun Komunikasi Positif antara Guru PAUD dan Orang Tua Murid (Selama Kebijakan Belajar dari Rumah) [Building Positive Communication between Early Childhood Education Teachers and Parents (During Learning from Home Policy)]. Jakarta: Kementerian Pendidikan dan Kebudayaan.

Kebudayaan, K. P. d. (2020h). Penilaian Perkembangan Anak Selama Belajar Dari Rumah [The Assessment of Child Development during Learning from Home]. Jakarta: Direktorat PAUD Kemdikbud 2020.

Kebudayaan, K. P. d. (2020i). Pentingnya Bermain bagi Anak Usia Dini [The Importance of Play for Very Young Children]. Jakarta: Kementerian Pendidikan dan Kebudayaan.

Kebudayaan, K. P. d. (2020j). Rencana Pelaksanaan Pembelajaran [Lesson Plan]. Jakarta: Direktorat PAUD Kemdikbud 2020.

Kim, D. D., \& Neumann, P. J. (2020). Analyzing the Cost Effectiveness of Policy Responses for COVID19: The Importance of Capturing Social Consequences. Medical Decision Making, 40(3), 251253. Retrieved from https://journals.sagepub.com/doi/abs/10.1177/0272989X20922987. doi:10.1177/0272989x20922987

Kim, J. (2020). Learning and Teaching Online During Covid-19: Experiences of Student Teachers in an Early Childhood Education Practicum. International Journal of Early Childhood, 52(2), 145158. Retrieved from https://doi.org/10.1007/s13158-020-00272-6. doi:10.1007/s13158020-00272-6

Makdori, Y. (2020, 20 September 2020). Kemendikbud Sebut Jumlah Siswa Baru PAUD Turun Selama Pandemi Covid-19. liputan6.com. Retrieved from https://www.liputan6.com/news/read/4363693/kemendikbud-sebut-jumlah-siswa-barupaud-turun-selama-pandemi-covid-19 
Maloney, E. A., Converse, B. A., Gibbs, C. R., Levine, S. C., \& Beilock, S. L. (2015). Jump-Starting Early Childhood Education at Home:Early Learning, Parent Motivation, and Public Policy. Perspectives on Psychological Science, 10(6), 727-732. Retrieved from https://journals.sagepub.com/doi/abs/10.1177/1745691615607064. doi:10.1177/1745691615607064

Millard, R. (2020, 12 March 2020). WHO declares Covid-19 outbreak a global pandemic. asiatimes. Retrieved from https://asiatimes.com/2020/03/who-declares-covid-19-outbreak-a-globalpandemic/

Pillay, A. L., \& Barnes, B. R. (2020). Psychology and COVID-19: impacts, themes and way forward. South African Journal of Psychology, 50(2), 148-153. Retrieved from https://journals.sagepub.com/doi/abs/10.1177/0081246320937684. doi:10.1177/0081246320937684

Putsanra, D. V. (2020, 28 August 2020). Panduan Kurikulum Darurat COVID-19 Buat Guru untuk Belajar Daring [The Guidance of Covid-19 Urgent Curriculum for Teachers during Online Learning]. tirto.id. Retrieved from https://tirto.id/panduan-kurikulum-darurat-covid-19buat-guru-untuk-belajar-daring-f1Vw

Rama, H. (2020, 14 September 2020). Siasati Pembelajaran Daring Selama Covid-19, Himpaudi Diminta Kembangkan Edukasi yang Kreatif [Strategy for Online Learning during the Pandemic Covid-19, HIMPAUDI is Asked to Develop Educational Activities Creatively]. wartakota.tribunnews.com. Retrieved from https://wartakota.tribunnews.com/2020/09/14/siasati-pembelajaran-daring-selamacovid-19-himpaudi-diminta-kembangkan-edukasi-yang-kreatif

Razavi, S., Behrendt, C., Bierbaum, M., Orton, I., \& Tessier, L. (2020). Reinvigorating the social contract and strengthening social cohesion: Social protection responses to COVID-19. International Social Security Review, 73(3), 55-80. Retrieved from https://onlinelibrary.wiley.com/doi/abs/10.1111/issr.12245. doi:https://doi.org/10.1111/issr.12245

Rolland, J. S. (2020). COVID-19 Pandemic: Applying a Multisystemic Lens. Family Process, 59(3), 922-936. Retrieved from https://onlinelibrary.wiley.com/doi/abs/10.1111/famp.12584. doi:https://doi.org/10.1111/famp.12584

Saputri, D. S. (2020, 16 June 2020). Dana BOS dan BOP PAUD Bisa Dipakai Beli Alat Kesehatan [Educational Fundings could be Allocated for Purchasing Health Equipment]. republika.co.id. Retrieved from https://republika.co.id/berita/qc06d8335/dana-bos-dan-bop-paud-bisadipakai-beli-alat-kesehatan

Sheth, K., Lorig, K., Stewart, A., Parodi, J. F., \& Ritter, P. L. (2020). Effects of COVID-19 on Informal Caregivers and the Development and Validation of a Scale in English and Spanish to Measure the Impact of COVID-19 on Caregivers. Journal of Applied Gerontology, O(0), 0733464820971511 . Retrieved from https://journals.sagepub.com/doi/abs/10.1177/0733464820971511. doi:10.1177/0733464820971511

Solekhah, H. (2019). PAUD is My Second Child: How Early Childhood in Indonesia Strives to Develop. International Journal of Emerging Issues in Early Childhood Education, 1, 121-133.

Trimuliana, I. (2020, 27 October 2020). Pulsa untuk BDR Bagi Guru dan Orang Tua PAUD [Pre-paid Vouchers for Learning at Home for Parents and Teachers in Early Childhood Education]. Retrieved

from https://anggunpaud.kemdikbud.go.id/index.php/berita/index/20201027113933/Pulsauntuk-BDR-Bagi-Guru-dan-Orang-Tua-PAUD

unicef.org. (2020). Covid-19 Parenting Tips. Retrieved from https://www.unicef.org/media/66146/file/COVID-19\%20parenting\%20tips.pdf

Yelland, N. (2020). Editorial. Contemporary Issues in Early Childhood, 21(3), 181-183. Retrieved from https://journals.sagepub.com/doi/abs/10.1177/1463949120953136. doi:10.1177/1463949120953136 
Yoshikawa, H., Wuermli, A. J., Britto, P. R., Dreyer, B., Leckman, J. F., Lye, S. J., . . Stein, A. (2020). Effects of the Global Coronavirus Disease-2019 Pandemic on Early Childhood Development: Short- and Long-Term Risks and Mitigating Program and Policy Actions. The Journal of Pediatrics, 223, 188-193. doi:10.1016/j.jpeds.2020.05.020

Yuliana, M. (2020, 27 October 2020). Does early childhood education still matter during COVID-19? Retrieved from https://www.thejakartapost.com/academia/2020/10/26/does-earlychildhood-education-still-matter-during-covid-19.html 